\title{
ChaRITABLE Foundations IN THE PRINCIPALITY OF LIECHTENSTEIN - TRADITION AND RECENT DEVELOPMENTS
}

\author{
Professor Dr Francesco A Schurr*
}

The purpose of this paper is to examine the evolution of the foundation (Stiftung) in the Principality of Liechtenstein. The article therefore deals with recent changes in the statutory legislation governing them as well as with current developments in case law. The paper will also address the different approaches taken towards foundations by the civil law and common law traditions within Europe. In fact, the jurisdiction of Liechtenstein embraces elements of both the civil and the common law traditions.

\section{INTRODUCTION}

When it comes to the establishment of non-profit organisations (NPOs), the world is divided into two: the Anglo-American common law world and the continental European civil law world. Both systems offer a broad range of legal instruments for the realisation of NPOs, such as the trust, the foundation, the association or the non-profit company. ${ }^{1}$ Any attempt to establish an NPO begins with choosing the ideal jurisdiction for realising a specific project. Since 1926, Liechtenstein has included within its legal system the civil law tradition of the foundation (Stiftung) having legal personality on one hand and the common law instrument of the trust (Treuhänderschaft) on the other hand. ${ }^{2}$

At present, charitable foundations (as well as mixed-purpose foundations) are expanding their role and gaining importance in various Member States of the European Union (EU) and the

* Chair of Company, Foundation and Trust Law, University of Liechtenstein, Vaduz.

1 Helmut K Anheier "Foundations in Europe: a comparative perspective" in Andreas Schlüter, Volker Then and Peter Walkenhorst (eds) Foundations in Europe (Bertelsmann Foundation, Directory of Social Change, London, 2001) 41

2 On the history of the law of foundations in Liechtenstein, see Dominique Jakob Die liechtensteinische Stiftung (Liechtenstein Verlag, Vaduz, 2009), at [1]-[3]. 
European Economic Area (EEA), such as Italy, Germany and Liechtenstein. ${ }^{3}$ As far as the legal frameworks for foundations are concerned, all of the legal systems seem to be facing similar problems.

At the end of the first decade of the 21st century, it seems to be en vogue for many natural persons and legal persons (such as companies) within Europe to establish foundations. Yet the pieces of statutory legislation regarding the legal instruments available are outdated in various states of Europe and cannot satisfy the demands of the modern globalised world of philanthropy. ${ }^{4}$

Recently, the Liechtenstein Legislature has revised the rules in order to adapt its legal framework to cope with the evolution that NPOs (and especially foundations) have undergone in Liechtenstein and in other EEA member states over the last few years. ${ }^{5}$ As a result, the Liechtenstein Legislature has created a new legal framework to meet the challenges facing today's foundations and addressed various key issues, such as the relationship between assets and goals, the level of transparency and accountability, the system of foundation governance, the external and internal supervision and permitting economic activity and so on.

This article will, for the most part, focus on the foundation as an instrument having legal personality and thus on the civil law tradition within Liechtenstein. At the end, the article will briefly give an introduction to the Liechtenstein trust (Treuhänderschaft) as an alternative instrument for the realisation of a charitable organisation in Liechtenstein.

\section{RECENT DEVELOPMENTS}

The foundation has had a long tradition in Liechtenstein. It was introduced into Liechtenstein law by the so-called Persons and Companies Act of 20th January 1926 (Personen- und Gesellschaftsrecht: "PGR"). ${ }^{6}$ The legislation on the law of foundations has recently been amended by Liechtenstein's Legislature. ${ }^{7}$ The Law of 26th June 2008 on the Amendment of the PGR entered into force on 1st April 2009. ${ }^{8}$ At the moment, practitioners as well as the courts in Liechtenstein are

3 See Klaus J Hopt, W Rainer Walz, Thomas von Hippel and Volker Then (eds) The European Foundation (Verlag Bertelsmann Stiftung, Gütersloh, 2007) 45.

4 For a comparative overview of the various systems in Europe, see for example Helmut $\mathrm{K}$ Anheier "Foundations in Europe: a comparative perspective" in Andreas Schlüter, Volker Then and Peter Walkenhorst (eds), above n 1, 35 .

5 For some background information on the reform, see Klaus Tschütscher "Das neue Stiftungsrecht - von der Herausforderung zur zukunftsorientierten Lösung" in Hochschule Liechtenstein (ed) Das neue liechtensteinische Stiftungsrecht (Schulthess, Zurich, 2008), at 1-6.

6 State Gazette 1926, at [4].

7 For a detailed overview of the legislation on companies and legal persons, see Marxer \& Partner Liechtensteinisches Wirtschaftsrecht (Liechtenstein Verlag, Vaduz, 2009), 33-46.

8 State Gazette 2008, at [220]. 
focused on implementing the new legislation in daily practice. The Liechtenstein law of foundations has been revised in order to meet the challenges of today's globalised market in the field of charitable activities and estate planning. Generally speaking, foundations pursue their goals as longterm projects and do not contain any corporate elements, such as shareholders or members. The Liechtenstein foundation is therefore typically a so-called non-membership-based organisation. As a consequence, a foundation requires a high degree of legal certainty, and achieving this was one of the major goals of the reform. ${ }^{9}$

\section{THE LIECHTENSTEIN FOUNDATION}

\section{A Definition of the Foundation}

A foundation is defined as a fund endowed for a specific purpose. ${ }^{10}$ On incorporation of the foundation, the fund becomes autonomous and acquires the status of a legal person. Incorporation therefore leads to assets being separated from those of its founder, and the foundation is entitled to the assets dedicated to it. ${ }^{11}$

The general definition and purpose of the foundation is contained in art $552 \S 1$ of the PGR. According to this provision, a foundation is deemed to be a legally and economically independent special-purpose fund. ${ }^{12}$ It is formed through a unilateral declaration of will made by the founder and is deemed to be a legal entity. After incorporation, the founder has to dedicate the foundation assets to the foundation. ${ }^{13}$ According to the rules in the Liechtenstein legislation, the founder has to stipulate the purpose of the foundation. This purpose has to be entirely non-self-serving and has to be specifically designated. As a result, specific beneficiaries must be designated by the founder.

\section{B Purpose of a Foundation}

According to art $552 \S 2$, the foundation under Liechtenstein law may be established for common-benefit or private-benefit purposes. A common-benefit foundation under Liechtenstein law must serve either non-profit purposes or charitable purposes. ${ }^{14}$ These purposes have to be in the

9 Martin Schauer "Grundelemente des neuen liechtensteinischen Stiftungsrechts und die rechtsvergleichende Perspektive" in Hochschule Liechtenstein (ed), above n 5, at 9-10.

10 For a comparative overview of the different definitions of foundations in Europe, see Andreas Schlüter, Volker Then and Peter Walkenhorst (eds), above n 1, at 29-30.

11 Martin Schauer "Art 552 § 1 PGR" in Martin Schauer (ed) Kurzkommentar zum liechtensteinischen Stiftungsrecht (Helbig Lichtenhahn Verlag, Basel, 2009) 6 at [5].

12 Dominique Jakob, above n 2, at [39].

13 For the special regime regarding the dedication of assets to a foundation that has been established mortis causa, see Helmut Heiss "Art 552 § 15 PGR" in Martin Schauer (ed) above n 11, 101 at [12]-[13].

14 See S D Prinz Michael von und zu Liechtenstein "Die konkreten Einsatzmöglichkeiten einer gemeinnützigen Stiftung" in Hochschule Liechtenstein (ed), above n 5, at 111-117. 
interest of the general public. The statutory provisions consider the purpose of a foundation to be for the benefit of the general public if the activity serves the common good in a charitable, religious, humanitarian, scientific, cultural, moral, sporting or ecological sense. Generally speaking, Liechtenstein law is very liberal. Thus, a foundation is regarded as being a non-profit-making (common-benefit) foundation whenever it focuses on one of the aforementioned purposes or a similar purpose, even if only a specific category of persons benefits from the activity of the foundation. ${ }^{15}$

\section{Relationship between Assets and Goals}

The endowment of assets can be made by natural or legal persons in the form of a deed, by will or by contract of inheritance. The minimum value of the assets of the foundation is to be set at 30,000 CHF. ${ }^{16}$ This amount must be put at the disposal of the foundation immediately, whereas a further dedication of assets can be undertaken at a later stage in the form of a subsequent endowment (for example, a donation). Furthermore, the amount of assets transferred by the founder (or by third persons) to the foundation and the costs incurred in order to realise the goals of the foundation must be proportionate. ${ }^{17}$ According to Liechtenstein law, it is fully permissible to establish a foundation which is dependent on the required assets being collected through fundraising in order to realise its goals. ${ }^{18}$

\section{Tradition, Development and Figures}

Since 1926, foundations have contributed significantly to the development of wealth in Liechtenstein. At the moment, there are approximately 40,000 foundations, most of which are private-benefit foundations, while around 800 foundations are public-benefit foundations. ${ }^{19}$ The number of public-benefit foundations is increasing very quickly at the moment.

In Liechtenstein, there are various types of foundations. With the exception of public law foundations, which do not fall under the private law legislation, there are charitable foundations, staff welfare foundations, company foundations, mixed family foundations, pure family foundations. The new Act has enormously enhanced the economic and social position of charitable

15 Martin Schauer "Art 107 PGR" in Martin Schauer (ed), above n 11, 1 at [2].

16 According to art $552 \S 13$ PGR it is allowed to dedicate alternatively 30,000 EUR or 30,000 USD.

17 Dominique Jakob, above n 2, at [54] and [55].

18 Dominique Jakob Der Schutz der Stiftung (Mohr Siebeck, Tübingen, 2006) at 64.

19 See these figures: Regierung des Fürstentums Liechtenstein "Statistik" (2009) Landesverwaltung Fürstentum Liechtenstein <www.llv.li/amtsstellen/llv-gboera-oera/llv-gboera-oera-amtsgeschaeftestatistik.htm>. 
foundations. In particular, the role of the new supervisory authority has considerably contributed to a greater acceptance of Liechtenstein as a jurisdiction in which to establish charitable NPOs. ${ }^{20}$

The provisions governing the Liechtenstein foundation were previously contained in arts 552 to 570 of the PGR which had been in force for over 80 years. In fact, Liechtenstein's economic prosperity has depended partly, or I would say rather substantially, on this piece of legislation. Many foundations, mainly for family purposes, have been established in Liechtenstein since then. The old legislation, which was in force until 31st March 2009, left various key subjects to the discretion of the courts since there was a lack of regulation in various areas. Some articles were even contradictory. Thus, the new rules (arts $552 \S \S 1$ to 52 PGR) have been welcomed by the legal community in Liechtenstein and abroad because it has created a greater degree of legal certainty. ${ }^{21}$ It is exceptional that the Liechtenstein law of foundations is embedded into the very liberal system of company law. ${ }^{22}$ The higher level of legal certainty has mainly been achieved through a clearer structuring of the new provisions. There is now a stricter line separating charitable foundations from private-benefit foundations. $^{23}$

The old provisions contained a reference to the law on the trust enterprise, which is governed by art 932a $\S \S 1-170$ of the PGR. In accordance with the previous art $552 \S 4$ PGR, these provisions on the trust enterprise had to be applied by analogy to foundations if the specific rules did not provide a definite solution. The following problems which had been debated for a long time by the Liechtenstein courts have now been clarified by the new legislation. ${ }^{24}$

\section{E Purpose of the Foundation}

A foundation is deemed to be a charitable foundation if it follows purely or predominantly charitable purposes. According to a quantitative evaluation, whether a mixed foundation predominantly follows private or charitable purposes must be established at the outset. ${ }^{25}$ It should be highlighted that a foundation may be established as a private-purpose foundation for a period of time and then automatically switch to being a charitable-purpose foundation or vice versa. ${ }^{26}$ This

20 Bernd Hammermann "Die beim Grundbuch- und Öffentlichkeitsregister in Vaduz angesiedelte neue Stiftungsaufsichtsbehörde" in Hochschule Liechtenstein (ed), above n 5, at 68-81.

21 Martin Schauer "Grundelemente des neuen liechtensteinischen Stiftungsrechts und die rechtsvergleichende Perspektive" in Hochschule Liechtenstein (ed), above n 5, at 9-43.

22 Dominique Jakob, above $\mathrm{n}$ 2, at [4]-[8].

23 Martin Schauer "Art $552 \S 1$ PGR" in Martin Schauer (ed), above n 11, 6 at [6]-[9].

24 Dominique Jakob, above n 2, at [23].

25 On the mixed-purpose foundation, see S D Prinz Michael von und zu Liechtenstein "Die konkreten Einsatzmöglichkeiten einer gemeinnützigen Stiftung" in Hochschule Liechtenstein (ed), above n 5, at 114115 .

26 Martin Schauer "Art 552 § 2 PGR" in Martin Schauer (ed), above n 11, 20 at [9]-[10]. 
enormous flexibility made available under the new Liechtenstein legislation enables the founder to combine various intentions: a founder who intends to assign certain assets to his or her children until they have reached a certain age and earn a certain level of income, and then wishes to assign the assets of the foundation to a charitable purpose in order to avoid "spoiling" his or her children can realise this plan under Liechtenstein law. A predominantly private foundation that also has a charitable element is not subject to supervision by the public supervisory authority, but is monitored by the beneficiaries through their right to information.

\section{F Formation of the Foundation and Acquisition of Legal Personality}

Charitable foundations acquire their legal personality only upon entry into the public registry, whereas private-benefit foundations acquire their legal personality through formation. Depositing the formation notification is merely of declarative nature and is not essential for the acquisition of legal personality.

The so-called incorporation (acquisition of legal personality) is not necessarily dependent on the foundation being registered, since only public-purpose foundations or those private-purpose foundations which carry on commercial activities need to be entered into the registry to acquire legal personality. ${ }^{27}$ The regime of foundation governance varies greatly depending on whether the foundation is registered or not. Only foundations that have been registered are automatically subject to the supervision of the public supervisory authority. ${ }^{28}$

It has always been possible under Liechtenstein law to create a private-purpose foundation (such as a family foundation) through a so-called fiduciary (Treuhänder) ${ }^{29}$ As a matter of fact, there are very few founders who actually establish their foundations themselves. Traditionally, the fiduciary, not the principal, was deemed to be the founder. ${ }^{30}$ According to the new art $552 \S 4$ PGR, the principal is regarded as the founder. ${ }^{31}$ This rule is particularly important when considering the fact that the founder's intentions sometimes have to be investigated at a later stage in order to be able to interpret the foundation documents properly. In this context, it should be highlighted that the principal's identity is generally not disclosed to the registrar. ${ }^{32}$ This is however only true for deposited foundations, and does not apply to so-called registered foundations.

27 Dominique Jakob, above n 2, at [130]-[143].

28 Bernd Hammermann "Die beim Grundbuch- und Öffentlichkeitsregister in Vaduz angesiedelte neue Stiftungsaufsichtsbehörde" in Hochschule Liechtenstein (ed), above n 5, at 69-70.

29 Harald Bösch Liechtensteinisches Stiftungsrecht (Stämpfli Verlag, Bern, 2005), at 303.

30 Liechtenstein Supreme Court (Oberster Gerichtshof, OGH) 6th December 2001, LES 2002, 41.

31 Martin Schauer "Art 552 § 4 PGR" in Martin Schauer (ed), above n 11, 27 at [13].

32 Bernd Hammermann "Art 552 § 20 PGR" in Martin Schauer (ed), above n 11, 119 at [6]-[9]. 
The notification of formation must include the foundation's name, domicile, purpose, the date of its formation, and its duration (if it is temporary). ${ }^{33}$ Moreover, the notification must contain the details of the foundation's organisation and its legal representatives, including their first and last names, dates of birth, nationalities and places of residence or registered office, or the corporate name of the members of the foundation council, as well as the form of the signatories' power. Furthermore, the formation notification must confirm that the beneficiaries or the class of beneficiaries have been determined in accordance with art $552 \S 20$ PGR. The information contained in the formation notification needs to be attested by a Liechtenstein lawyer, a trustee or a holder of an entitlement pursuant to art 180a PGR. ${ }^{34}$

The new provision of art $552 \S 21$ provides that, in its capacity as the supervisory authority, the Office of Land and Public Registration is entitled to verify the accuracy of the deposited notifications of formation and amendment. It may demand information through a controlling body or an auditor. ${ }^{35}$

\section{$G$ Bodies of the Foundation}

\section{Foundation council}

The new law of foundations stipulates that there is only one mandatory body of the foundation: the foundation council. As the executive body of the foundation, it must be composed of at least two members. ${ }^{36}$ The term of office is generally three years (art $552 \S 24(3)$ PGR) and a re-election is generally permissible. ${ }^{37}$

The foundation council members of charitable foundations often act for the public good without payment. If members of the foundation council act without remuneration, liability for minor negligence may be excluded in the declaration of establishment, unless the creditors of the foundation are adversely affected thereby. ${ }^{38}$

According to art 182 PGR, the foundation council shall diligently manage and promote the enterprise of the legal entity and shall be liable for observing the principles of diligent management and representation.

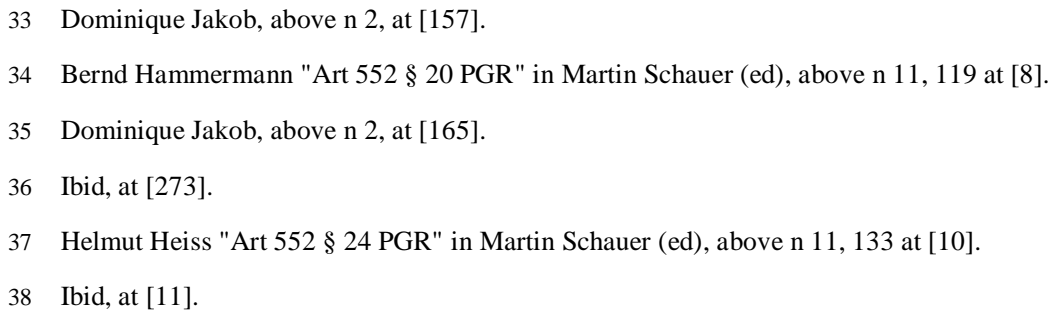


The new law of foundations now adheres to the internationally recognised business-judgement rule: According to art 182 PGR, a member of the foundation council shall be deemed to be acting in accordance with the principles of diligent management and representation if, in his or her commercial decision-making, he or she is not guided by irrelevant interests and if it may reasonably be assumed that he or she is acting for the good of the legal entity on the basis of appropriate information. ${ }^{39}$

\section{Controlling body}

According to the very liberal principles of the modern law of foundations in Liechtenstein, it is possible to establish other bodies which assist the foundation council in its work or have a supervisory role, for example a controlling body (protector) for the internal supervision. ${ }^{40}$

Generally, an audit authority is eligible to be a controlling body. The founder may also nominate as protector(s) one or more natural persons specified by name, who have sufficient specialist knowledge in the areas of law and business. The foundation documents may transfer the power of supervision to the founder too. ${ }^{41}$

According to art $552 \S 11$ and art $552 \S 27$ the controlling body must be independent of the foundation. The controlling body shall be under an obligation to verify once a year whether the foundation assets are being managed and appropriated in accordance with their purposes. The foundation council shall submit a report on the outcome of this audit. If there is no reason for objection, it shall be sufficient to provide confirmation that the foundation assets have been managed and appropriated in accordance with the purpose of the foundation and in conformity with the provisions of law and the foundation documents. ${ }^{42}$

\section{Additional executive body}

According to art $552 \S 28$ PGR, the founder may designate additional executive bodies, which in general however have no power of representation. ${ }^{43}$ Especially in the field of charitable foundations with large amounts of beneficiaries, it might be useful to establish a body that specifies a beneficiary from the category of beneficiaries. In addition, the task of determining the time, level and condition of a distribution may be assigned to such a body. Supervisory bodies are typically responsible for managing assets, for advising and assisting the foundation council, for monitoring the

39 Johannes Gasser "Neue Pflichten und Gestaltungsmöglichkeiten des Stiftungsrates" in Hochschule Liechtenstein (ed), above $\mathrm{n}$ 5, at 166-170.

40 Dominique Jakob, above n 2, at [403].

41 Bernhard Lorenz "Art 552 § 11 PGR" in Martin Schauer (ed), above n 11, 81 at [4]-[7].

42 Dominique Jakob, above n 2, at [400]-[402].

43 Helmut Heiss "Art $552 \S 28$ PGR" in Martin Schauer (ed), above n 11, 155 at [12]-[13]. 
administration of the foundation in order to safeguard the purpose of the foundation, for withholding consent or issuing instructions, as well as for safeguarding the interests of the foundation participants. $^{44}$

\section{H Types of Beneficiaries}

A key element of the law of foundation in every jurisdiction of the world is the definition of the beneficiaries. ${ }^{45}$ According to art $552 \S 5$ PGR, the beneficiary has to be a natural person or a legal entity. During the legal existence of the foundation or on its termination, the beneficiary might be entitled to receive a financial benefit. The beneficiaries are the target group of any foundation and thus play a key role for every foundation established under the Liechtenstein law of foundations. ${ }^{46}$

It is necessary to draw a clear line between the various types of beneficiaries: ${ }^{47}$ So-called entitled beneficiaries have a legal claim to a financial benefit from the foundation, irrespective of whether this is for or without valuable consideration, unconditional or subject to certain prerequisites or conditions, for a limited or unlimited period, with or without restrictions, revocable or irrevocable. ${ }^{48}$ Generally speaking, the new Liechtenstein legislation has achieved a higher level of legal certainty regarding the question of whether beneficiaries have, to a specified or a specifiable extent, a legal claim to benefit from the foundation assets or foundation income. Entitled beneficiaries have the strongest position.

Most foundations only have so-called prospective or discretionary beneficiaries. A prospective beneficiary is a beneficiary who, on occurrence of a condition precedent or at a specified time (for example, after the exclusion of a prior-ranking beneficiary), has a legal claim to acquire an entitlement. ${ }^{49}$ The discretionary beneficiary is a beneficiary whose possible beneficial interest is placed within the discretion of the foundation council or another body appointed for this purpose. A further, even weaker category is that of a beneficiary who merely has an expectancy to a future beneficial interest; this type of beneficiary is not to be treated as a discretionary beneficiary (art 552 $\S 7$ PGR). Discretionary beneficiaries actually only obtain a legal claim if a valid resolution is made by the foundation council or another executive body vested with this responsibility.

44 Dominique Jakob, above n 2, at [411]-[416].

45 Bernhard Lorenz "Art 552 § PGR" in Martin Schauer (ed), above n 11, 36 at [3].

46 Liechtenstein Supreme Court (Oberster Gerichtshof, OGH) 6th September 2001, LES 2002, 94.

47 Alexander Lins "Die Begünstigtenrechte im neuen liechtensteinischen Stiftungsrecht" in Hochschule Liechtenstein (ed), above n 5, at 86-89.

48 Liechtenstein Supreme Court (Oberster Gerichtshof, OGH) 6th March 2007, LES 2008, 279.

49 Bernhard Lorenz "Art 552 § 7 PGR" in Martin Schauer (ed), above n 11, 39 at [1]-[2]. 
Lastly, there is the category of ultimate beneficiaries. These beneficiaries receive the remaining assets following the liquidation of the foundation ( $\operatorname{art} 552 \S 8$ PGR). ${ }^{50}$

\section{System of Foundation Governance as Key Element of Transparency}

It should be noted that the most efficient form of supervising the foundation council as the executive body is through the beneficiaries taking an active role. However, many jurisdictions in Europe do not grant the beneficiaries any supervisory role in the overall dynamics of foundation governance. ${ }^{51}$ Especially when the general public is regarded as the ultimate beneficiary of a charity, natural or legal persons who have the status of beneficiaries according to the foundation documents normally do not have any legal rights. Hence, in most European jurisdictions, the role of supervision is assigned to public supervisory authorities.

\section{Transparency through internal foundation governance}

In contrast to the general trend in Europe, foundation governance in Liechtenstein is primarily orientated towards the beneficiaries, especially where private-purpose ore mixed-purpose foundations are concerned. Under Liechtenstein foundation law, beneficiaries have a strong right to information. ${ }^{52}$ The new piece of legislation has tried to find an appropriate balance between the beneficiaries' need for information and the founder's desire for confidentiality. ${ }^{53}$

Beneficiaries, in general, have legitimate interests in receiving information concerning the existence of the foundation as well as about the fact that they are beneficiaries, regardless of the category to which they belong. They might have the status of entitled, prospective, discretionary or ultimate beneficiaries. ${ }^{54}$ These legitimate interests need to be safeguarded. Despite the fact that foundation bodies are normally chosen carefully by the founder, these bodies must be subjected to some sort of scrutiny. ${ }^{55}$

A foundation, therefore, resembles a company, where the executive bodies have to be supervised by the shareholders. Due to the fact that the foundation typically does not have any corporate elements and is thus "ownerless", alternatives for such supervision are required. It is for

50 Dominique Jakob, above n 2, at [431]-[432].

51 For example, Doralt, Hemström and Kalss "Commentary on Art 4.4" in Klaus J Hopt, W Rainer Walz, Thomas von Hippel and Volker Then (eds), above n 3, at 188-190.

52 Dominique Jakob, above n 2, at [474]-[475].

53 On the principle of proportionality, see Bernhard Lorenz "Art 552 § 9 PGR" in Martin Schauer (ed), above n 11, 41 at [42]-[44].

54 On the separation between entitled and discretionary beneficiaries, see Liechtenstein Supreme Court (Oberster Gerichtshof, OGH) 6th March 2007, LES 2008, 279.

55 Dominique Jakob, above n 2, at [442]. 
this reason that the founder's interests in confidentiality must not be given too much weight in the foundation. Otherwise, there would be the risk of the beneficiaries being placed in a very weak position, since they would have to rely on the "generosity" of those in a position to grant them a benefit (for example, the foundation council). ${ }^{56}$

The right to information is contained in art $552 \S 9$ PGR. ${ }^{57}$ The beneficiary is entitled to inspect the foundation documents. Furthermore, the beneficiary is entitled to information regarding the situation of the assets or other matters of the foundation. The beneficiary also has a right to make copies of the foundation documents. Yet, the rights to information are restricted: a beneficiary may ask for information only where his or her own interests are concerned. ${ }^{58}$ This poses a particular problem for beneficiaries who do not have a legal claim, as their interests are less likely to be involved and they will therefore have less chance of asking for information.

Since charitable foundations normally grant a benefit only at the discretion of the foundation council, the beneficiaries are left with hardly any rights to information. ${ }^{59}$ It is for this reason that a charitable foundation must be registered. Foundations registered under Liechtenstein law are subject to supervision by the foundation supervisory authority. Therefore, the public supervisory authority assumes the functional role that is typically assigned to the beneficiaries ( $a r t 552 \S 29$ PGR). Transparency is therefore guaranteed by an external element of foundation governance. ${ }^{60}$

With regard to private-purpose foundations, there are various other techniques for restricting the rights of the beneficiaries to information. Whenever the founder reserves the right to revoke the foundation (pursuant to art $552 \S 30$ PGR), the beneficiaries do not have a right to information (art $552 \S 10$ PGR). ${ }^{61}$ Here, the role of supervising the activities of the foundation remains with the founder. He or she retains this role until his or her death. Thereafter, the right to revoke the foundation ends and the beneficiaries definitively start exercising a supervisory role through their right to information. ${ }^{62}$

56 Martin Schauer "Grundelemente des neuen liechtensteinischen Stiftungsrechts und die rechtsvergleichende Perspektive" in Hochschule Liechtenstein (ed), above n 5, at 33.

57 Alexander Lins "Die Begünstigtenrechte im neuen liechtensteinischen Stiftungsrecht" in Hochschule Liechtenstein (ed), above n 5, at 89-94.

58 Bernhard Lorenz "Art 552 § 9 PGR" in Martin Schauer (ed), above n 11, 41 at [31]-[81].

59 Bernhard Lorenz "Art 552 § 12 PGR" in Martin Schauer (ed), above n 11, 89 at [1]-[2].

60 Dominique Jakob, above n 2, at [456]-[472].

61 Francesco A Schurr and Simone Büchel "Überlegungen zur Anpassung und Änderung des Stiftungszwecks durch den Stifter bzw. durch ein Organ der Stiftung" (2009) 4 Liechtenstein Journal, at 110-117.

62 On the right to revoke, see Martin Schauer "Art $552 \S 30$ PGR" in Martin Schauer (ed), above n 11, 167 at [4ss]. 
There is another option for the founder to restrict the rights of information of the beneficiaries. In the foundation documents, the founder may establish a so-called controlling body (art $552 \S 11$ PGR). ${ }^{63}$ The controlling body may be an auditor, the founder personally, or one or more natural persons who have sufficient knowledge in the field of law and business. The control body has the right to inspect the foundation documents on behalf of the beneficiaries. ${ }^{64}$ Thus, the beneficiaries are not allowed access to information in the foundation documents as well as regarding the situation of the assets. According to art $552 \S 11(5)$ PGR, the beneficiaries are authorised to request reports on the control body from both the foundation and the control body itself. ${ }^{65}$ In doing so, the beneficiaries always have the opportunity of monitoring whether the control body has been set up and is acting in accordance with the current provisions in Liechtenstein foundation law.

Supervised foundations have, broadly speaking, a very low level of internal foundation governance. Thus, those private-benefit foundations which are voluntarily subject to the supervision of the foundation supervisory authority do not grant the beneficiaries any right to information. Consequently, they are, in their governance structure, very similar to charitable foundations. ${ }^{66}$

\section{Transparency through external foundation governance}

Charitable foundations must have an auditor (art $552 \S 27(1)$ PGR). The auditor is to be appointed by the court only. Under certain circumstances, however, charitable foundations do not need an auditor, for example especially where a small foundation is concerned. The government has recently issued an executive order regarding the requirements for an exemption from the obligation to have an auditor. It is at the registrar's discretion, as the supervisory authority, to ascertain whether the requirements for not requiring an auditor have been fulfilled. ${ }^{67}$

The foundation supervisory authority monitors the work of the foundation councils of those foundations that are subject to supervision (public-purpose foundations, mixed foundations with predominantly public purposes, foundations with commercial activity and private-purpose foundations which are voluntarily subject to the supervision). ${ }^{68}$ The foundation supervisory authority is entitled to demand information from the foundation and to inspect the accounts and

63 Dominique Jakob, above n 2, at [403].

64 Martin Schauer "Grundelemente des neuen liechtensteinischen Stiftungsrechts und die rechtsvergleichende Perspektive" in Hochschule Liechtenstein (ed), above n 5, at 36.

65 Bernhard Lorenz "Art $552 \S 11$ PGR" in Martin Schauer (ed), above n 11, 167 at [10].

66 Dominique Jakob, above n 2, at [473].

67 Art 552 § 27(5) PGR; art 5 and art 6(2)(b) StRV; Regierung des Fürstentums Liechtenstein "Home Grundbuch- und Öffentlichkeitsregisteramt (GBOERA)" Landesverwaltung Fürstentum Liechtenstein <www.llv.li/llv-gboera-home.htm>.

68 Dominique Jakob, above n 2, at [456]-[472]. 
documents of the foundation. This predominantly takes place through the audit authority. Whenever the foundation has been exempted from having an audit authority, the foundation supervisory authority exercises the right of inspection itself. ${ }^{69}$

It should be highlighted that, for additional measures, the supervisory authority needs to apply, in special non-contentious civil proceedings, to the court for the required orders. ${ }^{70}$ The supervision and dismissal of the executive bodies of the foundation is only permissible following an order of the court. ${ }^{71}$ Furthermore, the same applies to special audits or the rescission of resolutions passed by of executive bodies of the foundation, which require a prior order of the court (art $552 \S 29$ (3) PGR).

\section{Multi-layered system of foundation governance}

The Liechtenstein regime of foundation governance is therefore very sophisticated for the public-purpose foundation. The new law of foundations contains a multi-layered approach for foundation governance. First, there is one level of supervision through the beneficiaries, which is especially suitable for private-purpose foundations. Second, there is direct supervision by the public supervisory authority for public-purpose foundations. For this, however, the public supervisory authority needs to rely on internal control bodies, such as the audit authority. The audit authority itself is considered as an internal control body even though it has a public role. ${ }^{72}$ Moreover, there is the additional component of Liechtenstein's very liberal company law: it enables a founder to establish control bodies whose functions are determined by the foundation documents and which partly replace the right of the beneficiaries to information.

\section{J Transparency of the Assets}

Foundations carrying on businesses run along commercial lines are subject to the general rules on accounting (art 1045 PGR). ${ }^{73}$ The foundation council of other (non-commercial) foundations must, in respect of the management and appropriation of the foundation assets and taking into consideration the principles of proper book-keeping, maintain appropriate records of the financial circumstances of the foundation and keep documentary evidence presenting a comprehensible account of the course of business and movement of the foundation assets. ${ }^{74}$ In addition, the

69 Helmut Heiss "Art 552 § 27 PGR" in Martin Schauer (ed), above n 11, 148 at [2]-[3].

70 Dominique Jakob, above n 2, at [461]-[462].

71 Bernd Hammermann "Art 552 § 29 PGR" in Martin Schauer (ed), above n 11, 161 at [9]-[12].

72 The distinction is essential for the issue of the liability of the audit authority. See Helmut Heiss "Art 552 § 27 PGR" in Martin Schauer (ed), above n 11, 148 at [20]-[21].

73 Helmut Heiss "Art 552 § 26 PGR" in Martin Schauer (ed), above n 11, 146 at [2].

74 Dominique Jakob, above n 2, at [631]-[632]. 
foundation council must maintain a schedule of assets showing the asset position and the asset investments.

\section{THE LIECHTENSTEIN TRUST}

\section{A Anglo-American Elements within Liechtenstein}

As mentioned earlier in this paper, the legal system of Liechtenstein has embraced both the civil law and common law traditions since the PGR entered into force in 1926: Liechtenstein was the first continental European jurisdiction to enact statutory legislation regarding the trust as an institution deriving from the Anglo-American tradition. The provisions on the trust are contained in arts 897 to 932 of the PGR.

\section{B Choice between Instruments with and without Legal Personality}

The Liechtenstein legal system therefore enables the structure of an NPO to be organised either as an incorporated body having legal personality (foundation, Stiftung) or as a trust (Treuhänderschaft). The large portfolio of legal instruments available makes Liechtenstein a very attractive jurisdiction for realising foundations involving persons coming from civil law countries (such as Italy or Germany) as well as for persons from common law nations (such as the United Kingdom or the United States).

\section{Definition of a Trust according to the Law of Liechtenstein}

According to art 897 PGR, a trustee is a natural person, business or legal entity to whom another (the settlor) transfers movable or immovable property or a right of whatever kind. The trustee is under an obligation to administer or use such property in his own name as an independent legal owner for the benefit of the beneficiaries with effect towards other persons. Hence, the definition of the Liechtenstein trust follows the current definitions employed in typical trust jurisdictions.

\section{CONCLUSION}

In Liechtenstein, it is possible to establish an NPO following the continental European scheme of a foundation or the Anglo-American model of the trust. Both types are contained in the Liechtenstein legal system.

In its recent reform, the Liechtenstein legislature has created a new form of charitable foundation that is completely different from the private-purpose foundation. The new regime of the charitable foundation grants a high level of flexibility and of legal certainty through its modern approach of foundation governance. The reform of the law of foundations has significantly enhanced Liechtenstein's chances of being successful in the current competitive environment between the jurisdictions. 
The new legislation governing Liechtenstein foundations could serve as a model for the future of the European Foundation as well as for the various European states presently attempting to reform their national legislation on foundations. 
